\title{
Predator-Prey Relationships and Food Sources of the Skagerrak Deep-Water Fish Assemblage
}

\author{
O. A. Bergstad, Å. D. Wik and Ø. Hildre \\ Institute of Marine Research, Flødevigen Marine Research Station \\ N-4817 His, Norway
}

\begin{abstract}
The feeding ecology of fishes inhabiting the 300-700 $\mathrm{m}$ deep shelf trough of the central Skagerrak (northeastern North Sea) was investigated to identify major trophic pathways and analyse the relative significance of epipelagic, mesopelagic and benthic food sources. Two benthopelagic fish species, roundnose grenadier, Coryphaenoides rupestris, and greater silver smelt, Argentina silus, were highly dominant in this area, but the squalid shark Etmopterus spinax, the chimaera, Chimaera monstrosa, and the witch flounder, Glyptocephalus cynoglossus were also characteristic members of the deep fish assemblage.

Vertically migrating euphausids, shrimps (i.e. Pasiphaea sp.), copepods and hyperid amphipods were found to provide direct links between the epipelagic production and the deep-living roundnose grenadier. Prominent benthopelagic prey included the omnivorous Pandalus borealis and Sabinea sarsi. The trophic position of the greater silver smelt was uncertain because a high fraction of the stomach contents were unidentifiable, but a probable food source was thought to be mesopelagic and benthopelagic gelatinous plankton. Etmopterus spinax fed mostly on micronektonic crustaceans such as euphausids, but may have also scavenged on fish carcasses. Both the witch flounder and Chimaera monstrosa were benthophages feeding on a great variety of polychaetes, bivalves, gammarid amphipods and other medium-sized benthic prey.
\end{abstract}

Trophic transfer patterns observed in the Skagerrak were compared with results from slope waters and deep fjords.

Key words: Argentina, Coryphaenoides, deep-water, feeding, food web, Skagerrak

\section{Introduction}

Although displaying a wide range of feeding modes (e.g. Gartner et al., 1997), demersal deep-water fish ultimately depend on the transfer of energy from the productive epipelagic zone to the near-bottom zone. Many mechanisms facilitate this transport, but the vertical migration of mesopelagic nekton and macroplankton transferring energy deeper down the water column, that is by Vinogradov's "ladder of migrations" (Vinogradov, 1997), is an important process, at least in oceanic waters. Migrating plankton and micronekton feed directly on surface production of phytoplankton and zooplankton, but also utilize organically enriched "marine snow" aggregates (e.g. Lampitt et al., 1993). Along the continental slopes, the impingement of mesopelagic organisms at certain depths during daytime has been shown to be particularly significant in providing food for demersal fish (Blaber and Bulman, 1987; Mauchline and Gordon, 1991; Gordon et al., 1995; Merrett and Haedrich,
1997; Haedrich, 1997). The result is a depth zone of high concentrations of benthopelagic macrofauna including demersal fishes with diets dominated by pelagic and benthopelagic organisms (e.g. copepods, euphausids, mysids, pelagic shrimps, mesopelagic fish).

Similar vertical energy transfer processes probably sustain fish and macrofauna inhabiting other but less extensive deep-water areas such as fjords or deep channels and troughs on the continental shelves. The major difference between these and the oceanic waters is that the productivity of the overlaying surface waters is substantially higher. In fjords, the pelagic production processes and vertical migration behaviour of mesopelagic fish and zooplankton has been studied extensively (Matthews and Heimdal, 1980; Hopkins et al., 1989; Giske et al., 1990; Richard and Haedrich, 1991; Kaartvedt, 1999; Bagøien et al., 2000). A feature of particular significance in fjords is the influence of advective processes on the abundance 
and production of zooplankton and micronekton (Aksnes et al., 1989; Kaartvedt, 1999). Although many fjords have characteristic assemblages of fishes inhabiting both deep pelagic habitats and the nearbottom zone (Tambs-Lyche, 1987; Mattson, 1981; Nash, 1985), few if any fjord studies have incorporated specific analyses of energy transfer patterns from surface layers to deep-living demersal fish.

Deep shelf troughs are less enclosed than fjords, and their circulation patterns may be different and less influenced by run-off from land. The vertical salinity structure is also less pronounced, yet as in fjords, low salinity water influenced by coastal processes overlay water of oceanic origin that fill the deeper parts of such troughs. Intermittent or persistent deepwater inflow provides a transport route for organisms from adjacent slope waters to the inner shelf areas. The near-surface water masses may sustain a much higher level of biotic production than that found in the adjacent slope or oceanic waters. Deep-water fish inhabiting shelf troughs and fjords thus live in water of oceanic character, but benefit from energy supply from both local near-surface production and advective production in the deep-water.

An example of such a shelf trough is the deepest eastern basin of the Norwegian Deep found in the northeastern North Sea and Skagerrak (Fig. 1). The central area of this trough has a depth range of 300$720 \mathrm{~m}$, thus it is markedly deeper than the adjacent areas of the North Sea and Skagerrak that are mostly shallower than $100 \mathrm{~m}$. This deep-water trough is inhabited by a fish species assemblage strongly dominated by two species usually associated with upper continental slope waters, i.e. roundnose grenadier Coryphaenoides rupestris, and greater silver smelt, Argentina silus (Bergstad, 1990a, Table 1). The species composition in this deepest part is distinctly different from that found in the comparatively shallow western areas of the Norwegian Deep that were studied extensively previously (Bergstad, 1990a; Bergstad, 1991a, b; Albert, 1993, 1994a, b). Most of the deepwater basin lies within the Skagerrak, a sea area well known for its high production of pelagic fish such as herring (Clupea harengus), mackerel (Scomber scombrus) and sprat (Sprattus sprattus) providing landings of 150-200 000 tons/year, and also substantial catches of demersal fish, deep-water shrimp (Pandalus borealis) and Norway lobster (Nephrops norvegicus) (ICES, 2001). The deep-water demersal fishes, viz roundnose grenadier, greater silver smelt and witch flounder (Glyptocephalus cynoglossus), are also being fished commercially in this area (Bergstad and Tveite, 1993; Gordon et al., 2002), and the annual landings of around 3000 tons of Roundnose grenadier and 500-1 000 tons of greater silver smelt are quite high, especially when considering the limited size of the area.

The Skagerrak deep-water basin represents an example of a deep shelf area with a highly productive epipelagic zone but also with a close circulatory connection with the continental slope provided by the

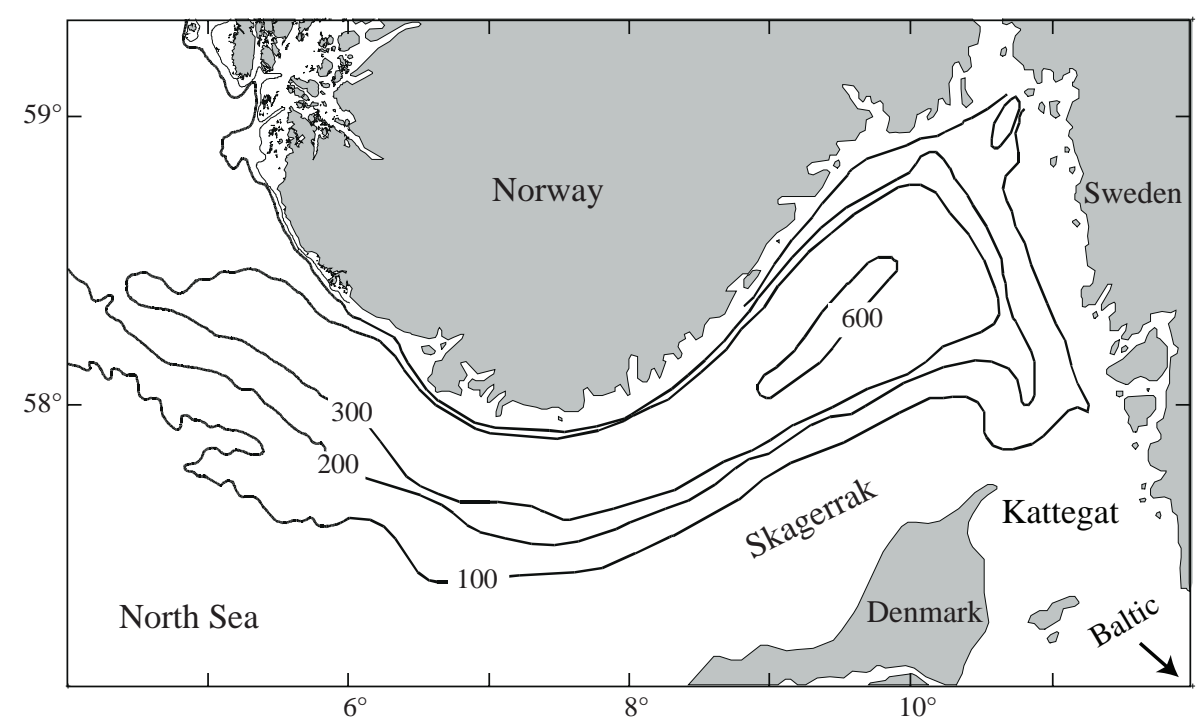

Fig. 1. The study area in the northeastern North Sea and the Skagerrak showing depths (m). 
TABLE 1. The ten most abundant species of the Skagerrak deep-water fish assemblage, giving percentage by weight $(\% \mathrm{~W})$ in bottom trawl catches during summer surveys in 1984-87. See Bergstad (1990a) for details.

\begin{tabular}{lc}
\hline \hline Species & $\% \mathrm{~W}$ \\
\hline Coryphaenoides rupestris & 51.7 \\
Argentina silus & 28.1 \\
Raja lintea & 5.5 \\
Chimaera monstrosa & 4.6 \\
Micromesistius poutassou & 1.8 \\
Etmopterus spinax & 1.7 \\
Molva dipterygia & 1.3 \\
Raja radiata & 1.3 \\
Glyptocephalus cynoglossus & 0.9 \\
Raja fyllae & 0.4 \\
Other species & 2.7 \\
\hline
\end{tabular}

inflow of Atlantic Water from the southern Norwegian Sea (Ljøen and Svansson, 1972; Otto et al., 1990; Aure and Dahl, 1994). In this paper focus is placed on feeding ecology of the fishes of the "Skagerrak deep-water assemblage" and on the processes that sustain fish production in this sub-system of the Skagerrak and North Sea. In addition to analyzing internal patterns in the deep community, a central aim has been to identify the essential trophic linkages between this sub-system and the fauna and production of the epipelagic zone. Processes that were assumed to be particularly significant for deep-water fishes were: 1) the diurnal and seasonal vertical migration of epi-pelagic and mesopelagic plankton and nekton, 2) the advective production of deep-water plankton or nekton, 3) local production of macrobenthos. An objective of this paper is to determine which of these processes are more significant to what fish species. The emphasis in this account is on patterns rather than rates, mainly because the studies were not sufficiently extensive nor designed to calculate transfer rates.

\section{Materials and Methods}

The analysis relies on data on the feeding habits of $C$. rupestris and $A$. silus derived from samples collected in the mid-1980s. In addition, unpublished information from Wik (MS 1994) on chimaera, Chimaera monstrosa, and squalid shark, Etmopterus spinax, and Hildre (MS 2001) on G. cynoglossus is summarized. To make the analysis sufficiently com- prehensive and to build a conceptual food-web model, data from previous accounts on rays (Skjæraasen, 1998); Skjæraasen and Bergstad, 2000, 2001), blue ling, Molva dipterygia, (Bergstad, 1991a), demersal juvenile C. rupestris (Mauchline et al., 1994), and mesopelagic fish larvae (Bergstad and Gordon, 1994) were also utilized. Despite that the data were collected over a range of years and not always simultaneously, it was assumed that any temporal changes were relatively minor and that major patterns would be stable in time. Previous studies of food-web patterns in the same or adjacent deep-water areas have either not considered linkages to major deep-water nekton species (e.g. Kiørbo et al., 1990), or focused on a limited taxonomic group or size-range (Bergstad 1991a, b; Mauchline et al., 1994).

\section{Study area}

The Skagerrak forms a Mediterranean sea between the Baltic and the North Sea (Fig. 1). This rather small area (about $36000 \mathrm{~km}^{2}$ ) has a wide variety of habitats ranging from the extensive 300-700 $\mathrm{m}$ deep muddy areas of the Norwegian Deep, to the shallow sandy banks along the Danish and Swedish coasts, the more rocky slope off Norway, and the highly productive surface waters associated with hydrographic fronts or eddies (e.g. Anon., 1993; Longva and Thorsnes, 1997). There is a general cyclonic circulation of both the surface and deep-water in the Skagerrak as water masses enter from the North Sea and the Kattegat in the southwest and south, and exit along the Norwegian Skagerrak coast as the Norwegian Coastal Current (Svansson, 1975; Rohde, 1996; Rydberg et al., 1996).

The group of fish species referred to as the "Skagerrak Deep-water assemblage" by Bergstad (1990a) has a distribution roughly delineated by the $300 \mathrm{~m}$ isobath and thus to some extent transgresses the conventional border of the Skagerrak $\left(7^{\circ} \mathrm{E}\right)$ westwards almost to $4^{\circ} \mathrm{E}$.

\section{Sampling}

The data on diets of $C$. rupestris and A. silus originated from research vessel cruises in 1984-87 that conducted either general fish community surveys or special surveys for Pandalus borealis. Bergstad (1990a, b; 1993) described in detail the sampling strategy, trawl gears, and sampling areas. The data on blue ling (Bergstad, 1991a), C. montrosa and E. spinax (Wik, MS 1994), and some samples of the three rays ( $R$. lintea, $R$. radiata, and $R$. fyllae) were also 
collected on the 1984-87 cruises. Glyptocephalus cynoglossus and supplementary samples of rays were sampled in 1995 and 1996. Hildre (MS 2001) and Skjaeraasen and Bergstad $(2000,2001)$ give details on the sampling in that period. On many of the cruises, sampling extended beyond the area inhabited by the fish assemblage considered in this paper. For the present analyses, only the data collected from the deepest inner basin of the Norwegian Deep were utilized, i.e. the areas deeper than $300 \mathrm{~m}$ to the east of $5^{\circ} \mathrm{E}$ (Fig. 1).

All specimens used in the diet analyses were measured and weighed. For all species except C. rupestris and C. monstrosa, total length (TL) from the tip of snout to tip of the caudal fin was used. Preanal length (AL) was used for C. rupestris and distance from snout to the posterior end-point of the second dorsal fin for C. monstrosa. Ungutted wet weight was recorded for most specimens.

Stomachs were usually extracted at sea and preserved in $4 \%$ buffered seawater solution of formaldehyde, and later transferred to $70 \%$ ethanol for conservation. Some of the ray and witch flounder stomachs were extracted from specimens brought frozen to the laboratory.

\section{Diet analyses}

Only contents of the section of the gut from the stomach (teleosts) or the forgut (elasmobranchs) were sorted and included in the analyses. After sorting and blotting on paper tissue, each prey category was weighed. Whenever possible, the prey were also measured and counted. In cases where only body fragments were found, the highest number of individuals from which these body parts could have originated was estimated.

The diet was characterized in terms of percentage by weight $(\% W)$ and in some cases numbers $(\% N)$, i.e.:

$$
\% W=\frac{W_{i}}{W_{\text {tot }}} * 100 \text { or } \% N=\frac{N_{i}}{N_{\text {tot }}} * 100
$$

where $W_{i}, N_{i}=$ weight or numbers of prey category $i$, and $W_{t o}, N_{t o t}=$ weight or numbers of all prey items of all non-empty stomachs considered.

On the basis of the diet analyses, a graphical representation of the trophic relationships was drawn, emphasizing the components and linkages that ap- peared most typical and important. No transfer rates or standing stocks of components were estimated, hence, this graphical diagram should only be regarded as a conceptual first step towards a more quantitative food-web model.

\section{Results}

\section{Diets of Individual Species}

Coryphaenoides rupestris. Data on diet of roundnose grenadier, C. rupestris, were collected in March and September, primarily in 1987. In total, 400 stomachs were examined of which 27 were empty. The composition of the contents in terms of percentage by weight and numbers by predator size-class are given in Table 2. Overall about $30 \%$ of the contents in terms of weight could not be assigned to any taxon. Twenty prey types were identified to species or genus, but identification to these levels was difficult because essential characters had been lost due to digestion. Of the identifiable contents, $96 \%$ was crustacean remains ranging from copepods to brachyurans. Fish remains occurred in very few stomachs. Blue whiting, Micromesistius poutassou, was only recorded once, and the remainder was mostly scales and unidentifiable fish tissue. Other non-crustacean taxa that occurred in small amounts were polychaetes, Clione limacina, nudibranchs and chaetognaths.

The number of stomachs from the smallest fish (AL 4-10 cm, TL $17.4-46.1 \mathrm{~cm}$ ) was only 12 , essentially too low to provide a satisfactory basis for comparisons with larger fish. Euphausids were prominent prey of this size-class, and the remainder was mostly other smaller crustaceans.

Among the grenadiers larger than $\mathrm{AL}=10 \mathrm{~cm}$, differences related to predator size were not very pronounced (Table 2, Fig. 2). The largest fish (AL $>16$ $\mathrm{cm}$ ) had higher proportions of the comparatively large P. borealis, and lower proportions of euphausids and other relatively small prey such as copepods and amphipods, compared with the smaller fish (AL 11$13 \mathrm{~cm}$ ). However, for all size-classes, the seasonal differences were rather marked (Fig. 2). The diet was more diverse in March than in September. Whereas the benthopelagic P. borealis and Pasiphaea spp. were prominent prey both in March and September, pelagic euphausids were only significant in March when this group alone contributed about $40 \%$ in terms of weight. Euphausids were almost absent in September, but then the crangonid shrimp Sabinea sarsi was an important prey. In March the latter was not recorded at all. 
TABLE 2. Stomach contents in terms of percentage by weight $(\% \mathrm{~W})$ and numbers $(\% \mathrm{~N})$ from all seasons in Roundnose grenadier, Coryphaenoides rupestris, in the Skagerrak.

\begin{tabular}{|c|c|c|c|c|c|c|c|c|}
\hline \multirow[t]{3}{*}{ Prey category } & \multicolumn{8}{|c|}{ Stomach contents by size-class (AL, $\mathrm{cm})$} \\
\hline & \multicolumn{2}{|c|}{$<11 \mathrm{~cm}$} & \multicolumn{2}{|c|}{$11-13 \mathrm{~cm}$} & \multicolumn{2}{|c|}{$14-16 \mathrm{~cm}$} & \multicolumn{2}{|c|}{$>16 \mathrm{~cm}$} \\
\hline & $\% \mathrm{~W}$ & $\% \mathrm{~N}$ & $\% \mathrm{~W}$ & $\% \mathrm{~N}$ & $\% \mathrm{~W}$ & $\% \mathrm{~N}$ & $\% \mathrm{~W}$ & $\% \mathrm{~N}$ \\
\hline Polychaeta & & & 0.02 & 0.10 & 0.55 & 0.24 & 0.14 & 0.11 \\
\hline Clione limacina & & & & & 0.00 & 0.01 & & \\
\hline Nudibranchia & & & & & & & 0.02 & 0.06 \\
\hline Crustacea indet. & 19.25 & 0.74 & 6.10 & 0.40 & 4.01 & 0.33 & 2.26 & 1.27 \\
\hline Ostracoda & & & & & 0.00 & 0.11 & & \\
\hline Calanoida & & & 0.02 & 0.40 & 0.04 & 2.36 & 0.00 & 0.42 \\
\hline Calanidae & & & & & 0.00 & 0.13 & & \\
\hline Calanus hyperboreus & & & & & 0.00 & 0.05 & & \\
\hline Calanus finmarchicus & & & 0.22 & 11.08 & 0.13 & 9.24 & 0.01 & 2.15 \\
\hline Chiridius armatus & 0.87 & 25.74 & 1.18 & 26.81 & 0.59 & 14.6 & 0.07 & 6.00 \\
\hline Pareuchaeta norvegica & 0.13 & 1.47 & 1.75 & 8.22 & 1.05 & 6.66 & 0.42 & 6.87 \\
\hline Leptostraca & 0.08 & 0.74 & & & & & & \\
\hline Mysidacea & & & & & & & 0.01 & 0.08 \\
\hline Mysidae & & & 0.03 & 0.27 & 0.04 & 0.27 & 0.01 & 0.23 \\
\hline Pseudomma sp. & 1.90 & 11.03 & & & & & & \\
\hline Idotea sp. & & & & & 0.02 & 0.01 & 0.01 & 0.06 \\
\hline Amphipoda & & & 1.77 & 14.90 & 1.44 & 9.08 & 0.03 & 0.82 \\
\hline Gammaridea & & & 0.08 & 0.23 & 0.13 & 0.28 & 0.14 & 1.19 \\
\hline Rhachotropis sp. & & & & & 0.01 & 0.01 & & \\
\hline Orchomenella obtusa & & & 0.01 & 0.03 & & & 0.01 & 0.06 \\
\hline Hyperiidae & & & 0.14 & 1.03 & 0.06 & 1.42 & 0.02 & 1.07 \\
\hline Parathemisto abyssorum & 3.19 & 20.59 & 3.26 & 20.39 & 5.29 & 35.92 & 1.69 & 35.56 \\
\hline Parathemisto gaudichaudi & & & & & & & 0.00 & 0.03 \\
\hline Eucarida & & & 0.93 & 0.03 & 1.33 & 0.1 & 0.47 & 0.06 \\
\hline Euphausiacea & & & 0.00 & 0.20 & 0.00 & 0.17 & 0.12 & 0.37 \\
\hline Euphausiidae & 56.03 & 36.76 & 6.68 & 11.98 & 7.23 & 13.18 & 4.09 & 18.64 \\
\hline Meganyctiphanes norvegica & 4.81 & 1.47 & 7.45 & 2.00 & 6.90 & 2.15 & 5.67 & 10.75 \\
\hline Decapoda & & & & & 0.08 & 0.03 & 0.27 & 0.03 \\
\hline Sergestes arcticus & & & 0.10 & 0.40 & 0.30 & 1.01 & 0.14 & 0.73 \\
\hline Caridea & 0.11 & 1.47 & 9.01 & 0.73 & 11.89 & 1.47 & 22.48 & 8.20 \\
\hline Pasiphaeidae & & & 5.56 & 0.23 & 2.84 & 0.18 & 2.26 & 0.31 \\
\hline Pasiphaea tarda & & & & & 0.60 & 0.01 & & \\
\hline Pasiphaea multidentata & & & & & 3.34 & 0.1 & 3.72 & 0.23 \\
\hline Pandalidae & & & & & 0.20 & 0.04 & 0.51 & 0.31 \\
\hline Pandalus borealis & & & 5.44 & 0.03 & 10.69 & 0.19 & 18.58 & 1.19 \\
\hline Crangonidae & & & 0.02 & 0.03 & 0.04 & 0.01 & 1.26 & 0.34 \\
\hline Sabinea sarsi & & & 1.84 & 0.27 & 2.04 & 0.24 & 6.12 & 2.32 \\
\hline Brachyura & 1.52 & 0.00 & 5.33 & 0.10 & 1.40 & 0.05 & 1.72 & 0.17 \\
\hline Chaetognatha & & & 0.01 & 0.07 & 0.01 & 0.03 & & \\
\hline Eukrohnia hamata & & & & & 0.01 & 0.01 & 0.00 & 0.03 \\
\hline Teleostei & & & 1.19 & 0.03 & 2.40 & 0.13 & 0.79 & 0.20 \\
\hline Micromesistius poutassou & & & & & 1.85 & 0.01 & & \\
\hline Coryphaenoides (scales) & & & & & 0.00 & 0.01 & 1.00 & 0.03 \\
\hline Indeterminatus & 12.11 & 0.00 & 41.87 & 0.03 & 33.49 & 0.15 & 25.96 & 0.11 \\
\hline Number of stomachs examined & 12 & & 103 & & 182 & & 103 & \\
\hline Numbers empty & 1 & & 12 & & 12 & & 2 & \\
\hline
\end{tabular}




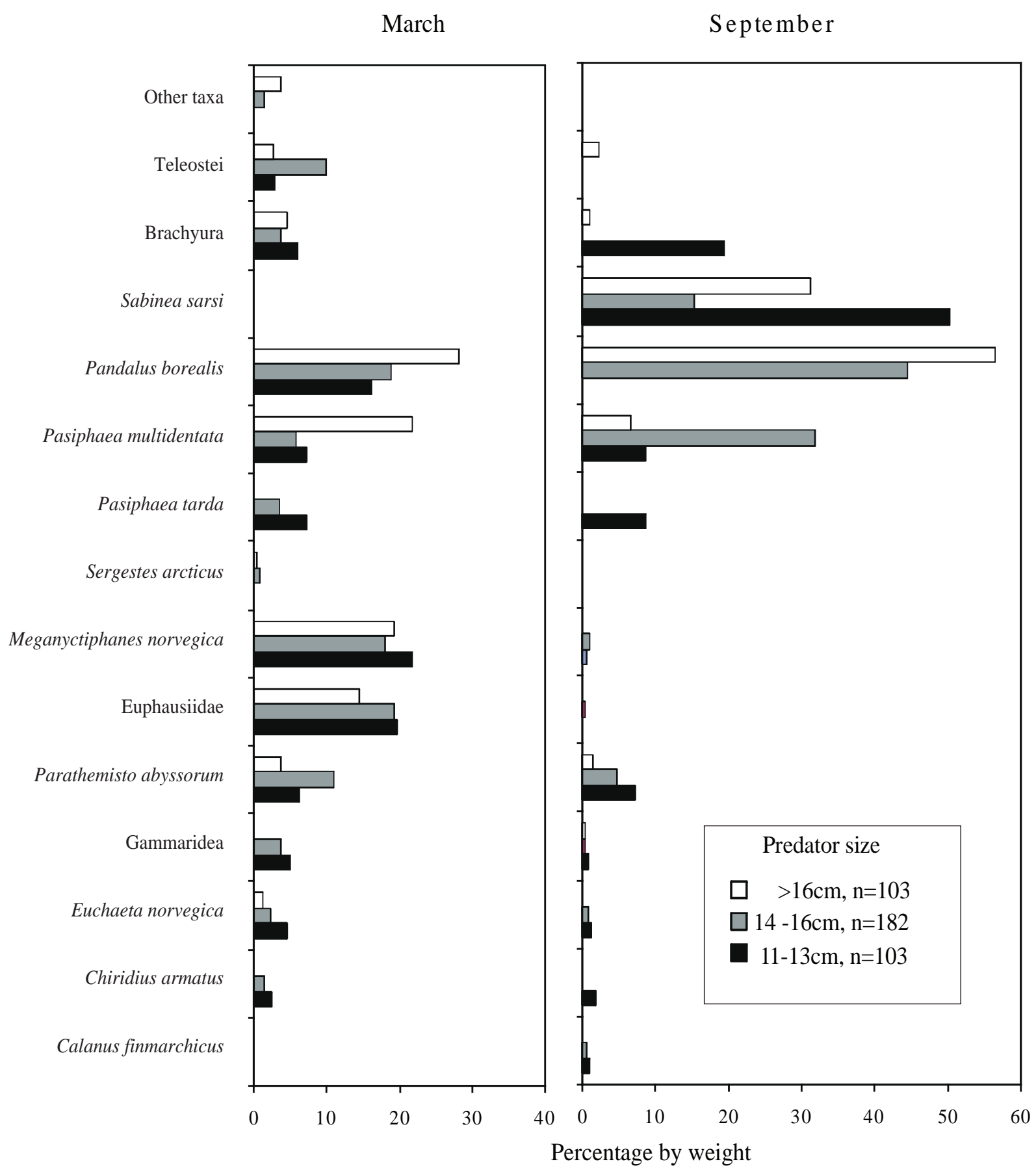

Fig. 2. Roundnose grenadier, Coryphaenoides rupestris. Diet by size-class and season. The diagram shows the proportion in terms of weight of all identifiable prey categories. For major taxa such as Crustaceans, prey items identified to higher levels were distributed proportionally to lower taxa within the group.

Argentina silus. In total, 397 stomachs of A. silus were examined, but 207 (52\%) were empty. The samples were collected in March-April and July-October. A summary of the contents in terms of weight and numbers is given in Table 3. A very high proportion of the contents remained unidentifiable even to high taxonomical levels. In the two most sampled sizeclasses (TL $>30 \mathrm{~cm}$ ), $94 \%$ of the contents in terms of weight fell into this category. The stomachs frequently contained an amorphous rather transparent substance 
TABLE 3. Stomach contents in terms of percentage by weight $(\% \mathrm{~W})$ and numbers $(\% \mathrm{~N})$ from all seasons, in greater silver smelt, Argentina silus, in the Skagerrak.

\begin{tabular}{|c|c|c|c|c|c|c|c|c|}
\hline \multirow[t]{3}{*}{ Prey category } & \multicolumn{8}{|c|}{ Stomach contents by size-class } \\
\hline & \multicolumn{2}{|c|}{$<20.0 \mathrm{~cm}$} & \multicolumn{2}{|c|}{$20.0-29.9 \mathrm{~cm}$} & \multicolumn{2}{|c|}{$30.0-39.9 \mathrm{~cm}$} & \multicolumn{2}{|c|}{$40.0-\mathrm{cm}$} \\
\hline & $\% \mathrm{~W}$ & $\% \mathrm{~N}$ & $\% \mathrm{~W}$ & $\% \mathrm{~N}$ & $\% \mathrm{~W}$ & $\% \mathrm{~N}$ & $\% \mathrm{~W}$ & $\% \mathrm{~N}$ \\
\hline Scyphozoa & & & & & 0.34 & 0 & & \\
\hline Polychaeta & & & 1.79 & 6.67 & 0.84 & 1.06 & & \\
\hline Tomopteridae & & & & & & & 0 & 0.57 \\
\hline Nudibranchia & & & 3.93 & 6.67 & 0.04 & 0.53 & 0 & 0.57 \\
\hline Crustacea & & & & & 0.81 & 1.06 & 0.1 & 0.57 \\
\hline Ostracoda & & & & & 0.01 & 5.32 & & \\
\hline Calanus finmarchicus & & & & & 0.06 & 7.98 & 0.01 & 5.68 \\
\hline Chiridius armatus & & & & & 0.06 & 14.36 & 0.06 & 13.64 \\
\hline Pareuchaeta norvegica & & & 1.03 & 13.33 & 0.02 & 1.06 & 0.02 & 1.14 \\
\hline Mysidae & & & 32.46 & 53.33 & 0.04 & 1.06 & 0.11 & 1.14 \\
\hline Hyperiidae & & & & & 0.01 & 0.53 & & \\
\hline Parathemisto abyssorum & & & 0.96 & 6.67 & 1.53 & 55.85 & 1.79 & 60.23 \\
\hline Euphausiidae & 100 & 100 & 15.37 & 13.33 & 0.07 & 0.53 & 0.59 & 2.84 \\
\hline Meganyctiphanes norvegica & & & & & 0.32 & 1.06 & 0.56 & 2.27 \\
\hline Sergestes arcticus & & & & & 0.05 & 0 & 0.01 & 1.14 \\
\hline Pasiphaeidae & & & & & & & 1.08 & 0.57 \\
\hline Pasiphaea multidentata & & & & & 1.03 & 0.53 & & \\
\hline Chaetognatha & & & & & 0.04 & 0.53 & & \\
\hline Eukrohnia hamata & & & & & & & 0.03 & 0.57 \\
\hline Teleostei & & & & & 0.61 & 8.51 & 1.95 & 9.09 \\
\hline Indeterminatus & & & 44.45 & 0 & 94.13 & 0 & 93.69 & 0 \\
\hline Number of stomachs examined & 14 & & 19 & & 259 & & 105 & \\
\hline Numbers empty & 8 & & 9 & & 123 & & 42 & \\
\hline
\end{tabular}

that when fixed in formaldehyde turned into a light yellow paste-like mass. The stomachs of small fish $(\mathrm{TL}<30 \mathrm{~cm})$ contained a higher proportion of identifiable items, primarily crustaceans

Pelagic and benthopelagic crustaceans dominated among the relatively minor fraction of the stomach contents that could be identified. The most consistent prey were euphausids, hyperid amphipods, mysids, and the large copepod Pareuchaeta norvegica. Except in the smaller size groups, all these contributed very little to the overall stomach content weight and may not be of great nutritional significance to A. silus. Fish remains were also present, but consisted mainly of scales of $C$. rupestris that may have been ingested in the net.

Etmopterus spinax. Wik (MS 1994) analysed stomach contents of E. spinax from the whole Norwegian Deep and provided extensive information on ontogenetic, spatial and seasonal variation. The data in Table 4 were based on a sub-set of the material used by Wik (MS 1994), including only samples from areas south of $59^{\circ} \mathrm{N}$ and east of $4^{\circ} \mathrm{E}$. The sample sizes were insufficient to analyse seasonal variation, but Wik (MS 1994) found only small seasonal differences in her more extensive analysis.

Ten prey items were identified to species or genus, and euphausids (i.e. Meganyctiphanes norvegica), shrimps (Pandalus borealis, Pasiphaea multidentata), and fishes were the main prey. The small sharks appeared to have a diet strongly dominated by euphausids. Among the identified fish prey, Weitzman's pearlside Maurolicus weitzmani occurred most frequently, whereas blue whiting Micromesistius poutassou was identified with certainty in only very few stomachs. Blue whiting was dominant in terms of weight. There was a large component of 'unidentified fish remains' comprising fish of various sizes, bones, and eye lenses. It is likely that most of these remains were pearlsides and blue whiting. Wik (MS 1994) also found large pieces of mackerel, herring, and cephalopods in a few stomachs and regarded these to be too big to be captured alive, hence she proposed that E. spinax had been scavenging. Inclusion of these 
TABLE 4. Stomach contents in terms of percentage by weight $(\% \mathrm{~W})$ and numbers $(\% \mathrm{~N})$ from all seasons, in squalid shark, Etmopterus spinax in the Skagerrak. Sub-set of data extracted from Wik (MS 1994).

\begin{tabular}{|c|c|c|c|c|}
\hline \multirow{3}{*}{ Prey category } & \multicolumn{4}{|c|}{ Stomach contents by size-class } \\
\hline & \multicolumn{2}{|c|}{$<20 \mathrm{~cm}$} & \multicolumn{2}{|c|}{$20-\mathrm{cm}$} \\
\hline & $\% \mathrm{~W}$ & $\% \mathrm{~N}$ & $\% \mathrm{~W}$ & $\% \mathrm{~N}$ \\
\hline Cephalopoda & 1.34 & 3.03 & 0.95 & 2.87 \\
\hline Crustacea & 1.92 & 3.03 & 0.12 & 1.59 \\
\hline Flabellifera & & & 0.03 & 0.32 \\
\hline Eucarida & & & 0.17 & 0.32 \\
\hline Euphausiidae & 0.57 & 3.03 & 0.27 & 3.82 \\
\hline Meganyctiphanes norvegica & 88.51 & 87.88 & 7.12 & 59.55 \\
\hline Thysanoessa longicaudata & & & 0.16 & 5.41 \\
\hline Caridea & & & 4.21 & 3.5 \\
\hline Pasiphaea sp. & & & 4.64 & 1.91 \\
\hline Pasiphaea multidentata & & & 10.39 & 5.41 \\
\hline Pandalus borealis & 7.66 & 3.03 & 12.42 & 5.1 \\
\hline Pandalus montagui & & & 1.4 & 0.32 \\
\hline Crangonidae & & & 0.98 & 1.27 \\
\hline Pontophilus sp. & & & 0.45 & 0.32 \\
\hline Pontophilus norvegicus & & & 1.89 & 0.32 \\
\hline Teleostei & & & 16.43 & 6.05 \\
\hline Maurolicus muelleri & & & 6.51 & 1.27 \\
\hline Gadidae & & & 2.4 & 0.32 \\
\hline Micromesistius poutassou & & & 29.47 & 0.32 \\
\hline Number of stomachs examined & 19 & & 128 & \\
\hline Numbers empty & 7 & & 56 & \\
\hline
\end{tabular}

few big items occurring in very few stomachs would have distorted the diet compositions entirely, and they were thus not included in the overall analyses, yet recognised as infrequent prey items.

Chimaera monstrosa. Wik (MS 1994) studied the diet of C. monstrosa in the entire Norwegian Deep based on samples from 1984-87 and 1992. She identified 74 prey to species or genus, but considered this to be an underestimate of the true number of species in the diet because many items were highly digested or fragmented. There was some ontogenetic variation in diet composition and prey size distributions, but insignificant seasonal variation.

Results for a sub-set of the material used by Wik (MS 1994), representing the area east of $4^{\circ} \mathrm{E}$ and south of $59^{\circ} \mathrm{N}$, is given in Table 5. In this table the stomach contents are aggregated at high taxonomic levels, and more detailed information is available in Wik (MS 1994). Benthic prey, i.e. polychaetes and bivalves were prominent in the diet of both the size-classes considered, showing that $C$. monstrosa was primarily benthophagous. Large crustaceans such as caridean shrimps and anomurans were significant prey of the large size-class. A wide range of smaller and predominantly benthic or hyperbenthic crustaceans also occurred in the stomachs but appeared to be of minor nutritional importance.

Glyptocephalus cynoglossus. Hildre (MS 2001) examined 134 stomachs of G. cynoglossus, all from the period March-October in 1991-92 and 1995-96, and from areas east of $7^{\circ} \mathrm{E}$ and the depth range $156-490 \mathrm{~m}$. In the 132 stomachs that contained food, he found a wide range of prey items, although $44 \%$ of the contents in terms of weight were unidentifiable (Table 6). Small benthic and hyperbenthic animals dominated the diet of all size-classes, and the richness was very high although difficult to estimate precisely, because many taxa could not be identified to species. On the basis of weight, $59.3 \%$ of the fraction was identified to higher taxonomical level as polychaetes, $20.4 \%$ bivalves, and $13.9 \%$ crustaceans. Twenty-three families of polychaetes were recorded, mainly Polynoidae, Sigalionidae, Capitellidae, Opheliidae, Cirratulidae, and Ampharetidae. The more prominent bivalve families were Scrobiculariidae and 
TABLE 5. Composition of the stomach contents in terms of percentage by weight $(\% \mathrm{~W})$ and numbers $(\% \mathrm{~N})$ from all seasons, in chimaera, Chimaera monstrosa, in the Skagerrak. Sub-set of data extracted from Wik (MS 1994).

\begin{tabular}{|c|c|c|c|c|}
\hline \multirow{3}{*}{ Prey category } & \multicolumn{4}{|c|}{ Stomach contents by size-class } \\
\hline & \multicolumn{2}{|c|}{$<40 \mathrm{~cm}$} & \multicolumn{2}{|c|}{$40 \mathrm{~cm}$} \\
\hline & $\% \mathrm{~W}$ & $\% \mathrm{~N}$ & $\% \mathrm{~W}$ & $\% \mathrm{~N}$ \\
\hline Foraminiferida & 0.73 & 3.33 & 0.82 & 3.43 \\
\hline Porifera & & & 0 & 0.12 \\
\hline Hydroida & & & 0.01 & 0.24 \\
\hline Polychaeta & 40.08 & 13.02 & 22.96 & 12.19 \\
\hline Gastropoda & 0.21 & 1.27 & 0.42 & 4.39 \\
\hline Bivalvia & 37.65 & 49.68 & 22.32 & 34.31 \\
\hline Cephalopoda & & & 0.01 & 0.12 \\
\hline Scaphopoda & 0.08 & 0.32 & & \\
\hline Crustacea, indet. & 0.1 & 1.27 & 0.07 & 0.71 \\
\hline Ostracoda & 0.04 & 1.9 & 0 & 0.36 \\
\hline Calanoida & 0.15 & 1.59 & 0.07 & 1.42 \\
\hline Lepadomorpha & 0.05 & 0.32 & 0.18 & 1.42 \\
\hline Leptostraca & & & 0.01 & 0.12 \\
\hline Mysidacea & & & 1.52 & 15.74 \\
\hline Cumacea & 0.36 & 6.19 & 0.02 & 0.36 \\
\hline Tanaidacea & 0.04 & 0.63 & 0.02 & 0.59 \\
\hline Isopoda & 1.37 & 0.32 & 1 & 2.37 \\
\hline Gammaridea & 1.64 & 13.49 & 2.21 & 7.22 \\
\hline Hyperiidea & & & 0 & 0.12 \\
\hline Euphausiacea & 0.11 & 0.32 & & \\
\hline Decapoda, indet. & 0.05 & 0.32 & 0.09 & 0.36 \\
\hline Caridea & 0.72 & 1.9 & 9.27 & 4.62 \\
\hline Anomura & 0.22 & 1.11 & 5.14 & 2.6 \\
\hline Ophiuroidea & 0.09 & 0.48 & 1.44 & 1.66 \\
\hline Ascidiacea & 2.59 & 0.95 & 3.6 & 0.95 \\
\hline Myxiniformes & & & 2.49 & 0.12 \\
\hline Teleostei & 0.03 & 0.48 & 2.11 & 2.96 \\
\hline Indeterminatus & 13.6 & 0.32 & 24.23 & 1.54 \\
\hline Number of stomachs examined & 95 & & 55 & \\
\hline Numbers empty & 27 & & 1 & \\
\hline
\end{tabular}

Nuculanidae. A wide range of crustaceans occurred, but caridean shrimps, brachyurans and pagurids contributed most in terms of weight. Further details on the diet composition and ontogenetic variation are given in Hildre (MS 2001).

Raja fyllae, $R$. lintea. Thirteen stomachs from $R$. fyllae were examined by Skjæraasen (1998) and he found that benthic prey such as polychaetes, crangonid shrimps and gammarid amphipods dominated in terms of weight. Few prey items could however be identified to species. Raja fyllae is the smallest of the three rays occurring in the area (8-68 $\mathrm{cm} \mathrm{TL}$ ), whereas $R$. lintea is the largest with a size range of 18-118 cm TL. Skjæraasen (1998) examined 24 stomachs of $R$. lintea, and that fish contributed $78 \%$ to the total weight of the contents. Identifiable prey species were blue whiting (Micromesistius poutassou), saithe (Pollachius virens) and greater silver smelt (A. silus). Other important food items were galatheid crabs (Munida sarsi) and shrimps, primarily Pontophilus sp. and Pandalus sp. The most common food item was Pontophilus norvegicus followed by unidentified fish and Munida sarsi. Unfortunately, for both these species the material was too limited to study size-related changes in diet.

\section{Other species}

The diet of $R$. radiata in the Norwegian Deep as a whole was analyzed by Skjæraasen and Bergstad (2000). A total of 175 stomachs were examined for food. Three prey categories contributed about $90 \%$ to the wet weight of the stomach contents. These were decapod crustaceans $(30 \%)$, polychaetes $(11 \%)$ and 
TABLE 6. Composition of the stomach contents in terms of percentage by weight (\%W) and numbers $(\% \mathrm{~N})$ from all seasons and size groups, in witch flounder, Glyptocephalus cynoglossus, in the Skagerrak. Data extracted from Hildre (2001).

\begin{tabular}{lrrr}
\hline \hline Prey category & $\begin{array}{c}\% \mathrm{~W} \\
\text { (indeterm. excluded) }\end{array}$ & $\begin{array}{c}\% \mathrm{~W} \\
\text { (indeterm. included) }\end{array}$ & $\% \mathrm{~N}$ \\
\hline Foraminiferida & 0.1 & + & 1.8 \\
Actiniaria & 5 & 2.8 & 0.1 \\
Polychaeta & 59.3 & 33.2 & 52.4 \\
Gastropoda & 0.8 & 0.5 & 0.2 \\
Bivalvia & 20.4 & 11.5 & 16.6 \\
Cumacea & 0.6 & 0.3 & 6.6 \\
Isopoda & 0.1 & 0.1 & 2.5 \\
Amphipoda & 1.2 & 0.7 & 12.1 \\
Euphausiacea & 0.2 & 0.1 & + \\
Decapoda & 10.3 & 5.8 & 2.2 \\
Other Crustacea & 1.5 & 0.8 & 0.4 \\
Echinodermata & 0.3 & 0.2 & \\
Teleostei & 0.1 & + & \\
Indeterminatus & & 43.9 & \\
Number of stomach examined & 134 & & \\
Numbers empty & 2 & & \\
\hline
\end{tabular}

bony fish (48\%). The large fraction of fish was partly attributable to a few large fish specimens eaten by large $R$. radiata. The most common fish prey was gadids, while the bulk of the decapods consisted of crangonids $(5.6 \%)$ and $P$. borealis. The polychaetes that could be identified belonged to three families, the Polynoidae, Sigalinoidae and Ophellidae.

The diet of the smallest $(<25 \mathrm{~cm}$ TL) and intermediate size rays (25-40 cm TL) consisted largely of polychaetes and shrimps. To the largest $R$. radiata (TL $>40)$, fish prey were most important in terms of weight, but large decapods other than shrimps became increasingly important, and Munida sarsi contributed $12 \%$ to the wet weight. Crangonids were replaced by the larger $P$. borealis. These results were based to a large extent on data from more western parts of the Norwegian Deep, yet the main patterns would very likely be representative for the Skagerrak deep-water.

The piscivorous nature of blue ling (Molva dipterygia) was shown by Bergstad (1991a) based on data from the Norwegian Deep. Both C. rupestris, A. silus, and M. poutassou were prey of this species. Blue whiting (M. poutassou) feeds mainly on pelagic crustaceans, and in the Norwegian Deep its main prey is euphausids (Bergstad, 1991a).

\section{Food-web model}

On the basis of the diet studies described above, a simplified graphical representation of the food web of the Skagerrak deep-water was drawn (Fig. 3), emphasising the food-sources and predator prey-relations of the two main deep-living fishes, C. rupestris and A. silus. Arrows indicate predator-prey linkages between species or important transfer processes such as sedimentation (hatched lines) or vertical migration (vertical lines).

\section{Discussion}

Previous research on deep-water fish of the Skagerrak have focused on assemblage structure (Bergstad, 1990a, b, 1991a,b), and on the biology and feeding ecology of selected species, genera or families (Bergstad, 1991, 1993; Albert, 1993, 1994a, b, Bergstad and Gordon, 1994; Mauchline et al., 1994; Skjæraasen and Bergstad, 2000, 2001). In this paper new feeding data on the two major species $C$. rupestris and $A$. silus and unpublished data on Etmopterus spinax, C. monstrosa and G. cynoglossus are integrated with other published accounts in order to provide the basis for a descriptive analysis of food-web relations, both within the community and between the deep fauna and the epipelagic community. 


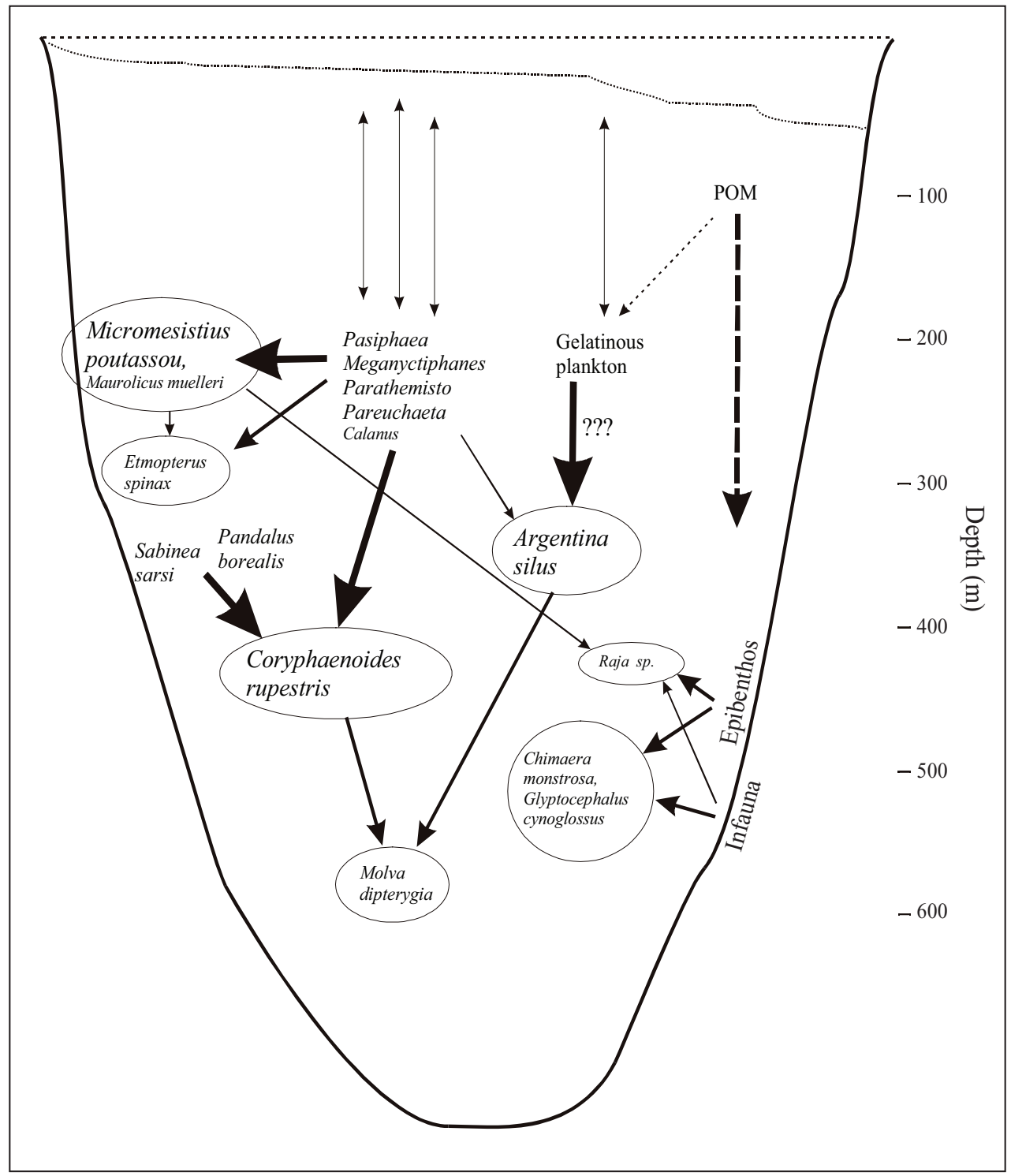

Fig. 3. Predator-prey relationships and transfer processes of the Skagerrak deep-water fish community. Arrows indicate predator-prey linkages between species or important transfer processes such as sedimentation (hatched lines) or vertical migration (vertical lines). Font size reflects relative abundance of taxa and thickness of arrows reflect assumed differences in significance/importance of energy transfers based on diet information and knowledge of relative abundance from trawl surveys.

In such an analysis, rather detailed information on the occurrence and behaviour of prey taxa is required, but unfortunately such information remains scarce. There is a comparatively extensive literature on benthic communities of the Skagerrak (e.g. Anon., 1993; Rosenberg et al., 1996; Miskov-Nodland et al., 1999) and some papers on crustacean mesozooplankton (e.g. Båmstedt, 1983; Kiørboe et al., 1990; Tiselius et al., 1991) and euphausids (e.g. Buchholz and Boysen-Ennen, 1988; Bøhle and Moksness, MS 1991). However, many important prey groups such as pelagic shrimps and gelatinous plankton do not seem to have been studied at all in this area. Comprehensive analyses linking information on individual taxa or communities with the view to understand processes underlying the extensive production of deep-water macrofauna, including commercial fish and crustaceans, have not been carried out. 
A central aim of the present work has been to identify the major trophic linkages between the deepwater sub-system and the fauna and production of the near-surface systems. In order to derive tentative conclusions on community patterns, data for individual species need to be considered in some detail. The diet studies of $C$. rupestris, the most abundant fish species of the Skagerrak deep-water assemblage, showed that pelagic of hyperbenthic crustaceans were dominant prey of all size-classes studied here. Pelagic juveniles feed mainly on copepods (Bergstad and Gordon, 1994), and demersal juveniles on small hyperbenthic crustaceans (Mauchline et al., 1994). Based on studies in other areas (Podrazhanskaya, 1968; Geistdorfer, 1978; Mauchline and Gordon, 1984), Gartner et al. (1997) placed this species in a guild of "Macronekton Foragers"(Guild 2) among other macronekton specialists primarily inhabiting upper and middle slope waters. Coryphaenoides rupestris has been caught and observed by echosounders several hundred metres above the seabed (Pechenik and Troyanovsky, 1970; Haedrich, 1974; Bergstad, 1990b), and may feed both demersally and pelagically. The pelagic euphausid, Meganyctiphanes norvegica, was prominent in the diet in March and may be most available in winter due to its descent into deep water (e.g. Mauchline, 1980, Onsrud and Kaartvedt, 1998). In summer and autumn, this omnivorous or carnivorous species (Mauchline, 1980; Båmstedt and Karlson, 1998) is very abundant at middepth during the day and ascends to the surface at night (Mauchline, 1980; Bergstad, 1991a). By feeding on euphausids in winter, $C$. rupestris essentially utilizes energy produced in the near-surface layer in the summer. The carnivorous shrimp, Pasiphaea multidentata, also carries out extensive vertical migrations and at least a fraction of the population ascends to the bottom of the near-surface mixed layer (Kaartvedt et al., 1988; Cartes, 1993; Cartes et al., 1993; Bergstad et al., 1996). This species was a relatively important element of the diet of $C$. rupestris in both seasons, and its feeding migration constitutes another transport route of energy and matter from the surface layer to the deep basin. The same may be the case for the carnivorous amphipod, Parathemisto abyssorum, the copepod, Pareuchaeta norvegica, and other copepods that were frequent prey yet probably of limited nutritional significance. Pandalus borealis may also occur pelagically at night, but seldom very far off the bottom (Shumway et al., 1985; Bergström, 2000). The same may be the case for another primary decapod prey, Sabinea sarsi. These are hyperbenthic animals that primarily rely on food sources produced in or transported to their near-bottom habitat, i.e. smaller hypoplanktonic or hyperbenthic organisms and detritus (Shumway et al., 1985; Squires, 1990; Bergström, 2000). Their prominence in the diet of $C$. rupestris expressed in terms of weight is partially due to their larger size compared with the pelagic crustaceans. Nonetheless, the results show that $C$. rupestris is sustained by both pelagic and hyperbenthic production. Truly benthic prey were however insignificant. Seasonal and diurnal vertical migration of pelagic crustaceans, and sedimentation providing food to hyperbenthic crustaceans, may be the primary processes channelling energy from the surface layer to the deep-water fish in this case.

Due to the high proportion of unidentifiable remains among the stomach contents, a similar logic is more difficult to apply to the second most abundant fish species, A. silus. Vertical migrants such as calanoid copepods, hyperiid amphipods and euphausids occurred in the diet, but were never prominent compared with the unidentifiable amorphous substance usually observed. High frequencies of empty stomachs and large proportions of unidentifiable contents have been noted in a number of previous diet studies of A. silus (Borodulina, 1964; Keysler, 1968; Mauchline and Gordon, 1983). Stomachs with unidentifiable contents have sometimes been disregarded as empty (Keysler, 1968). Pelagic crustaceans feature prominently in previous accounts from various parts of the North Atlantic (Borodulina, 1964; Emery and McCracken, 1966; Keysler, 1968; Wood and Raitt, 1968; Westhaus, 1982; Mauchline and Gordon, 1983). In some areas (Iceland, Faroes, Rockall) small mesopelagic fishes such as Cyclothone spp. and Chauliodus spp. may be important (Keysler 1968; Westhaus, 1982), primarily to large A. silus. Chaetognaths and gelatinous prey have been reported by many investigators, and Mauchline and Gordon (1983) found that $47.6 \%$ of the stomachs with identifiable remains contained salps or ctenophores.

The lack of dentition, the big eyes, the fusiform body and forked tail, and also the virtual absence of benthic prey in the stomachs, suggest that $A$. silus is a visual pelagic predator. The suspicion is that many earlier feeding studies have overemphasized the role of identifiable prey items, in particular crustaceans, in its diet. A suggestion is that $A$. silus rather belongs to a guild of pelagic specialists comprising species feeding on gelatinous plankton such as hydromedusae, ctenophores or salps, i.e. the "Macroplanktivore Guild 7" of Gartner et al. (1997). A. silus has a mouth mor- 
phology and overall appearance which is very similar to another species, Alepocephalus bairdii, known to feed on gelatinous plankton. Gelatinous prey become quickly digested beyond recognition and may, when preserved, appear amorphous. No studies of gelatinous plankton or their feeding have been reported from the Skagerrak deeps, but ctenophores are abundant and the hydromedusa, Tima bairdii, may occur in great abundance, even to the extent that bottom trawling for Pandalus spp. becomes hampered (Dybern, 1969).

Another two of the Skagerrak deepwater species, blue whiting (M. poutassou) and E. spinax, are also predominantly pelagic and benthopelagic predators, yet the latter is also possibly a scavenger. Only three species are strongly benthophagous, i.e. G. cynoglossus, C. monstrosa, and $R$. fyllae. The two first had very diverse diets consisting of both infauna and epifauna. Due to low sample size, the full diversity of the diet of $R$. fyllae may not have been observed. The remaining fishes have mixed diets consisting of relatively large prey, mostly large epibenthic or benthopelagic crustaceans and fish. This was the case for $R$. radiata. $R$. lintea, and also Molva dipterygia, the latter appearing strongly piscivorous.

In summary, the two dominant fish species in the deep-water, C. rupestris and A. silus, appear to rely heavily on pelagic production, albeit on different pelagic prey. Few fishes depend on local benthic production, but several species have mixed diets including hyperbenthic organisms. One of the main pathways leading energy and matter from the epipelagic zone to deep-living fishes is that maintained by the vertical migrating species of Meganyctiphanes, Pasiphaea, Parathemisto and the large migratory calanoid copepods.

The pelagic production in the epipelagic zone and in deepwater is probably strongly linked to (or even driven) by the very dynamic circulation system of the area. It has been suggested that there are at least three circulation and frontal features that strongly affect character and level of the biological production and transport of organisms. The first is the rather persistent front or eddy in the Kattegat-Skagerrak border area northeast of Cape Skagen, which is maintained by the merging of the inflowing North Sea water and the Baltic outflow (e.g. Rohde, 1996). The second feature, occurring in near-surface water along the shelfbreak on the southern side of the central deeps, is a rather persistent front between the relatively saline Atlantic Water and the inflowing mixed North Sea water. This is probably affecting production over wider areas including central Skagerrak waters. The cyclonic circulation results in a lifting of the sub-surface nutrient-rich Atlantic Watermass in the centre and a deepening of the mixed layer along the coasts. This often results in a summer "dome" or "ridge" of the pycnocline in the central area of the Skagerrak (Fonselius, 1996, Danielssen et al., 1997) that also influences the structure of the near-surface phyto- and zooplankton community (e.g. Kiørboe et al., 1990; Kahru and Leeben, 1991). The third feature, of particular significance for the deep-water community, is the sub-surface inflow of saline Atlantic Water along the southern slope of the deep-water basin (Rohde, 1996). The Atlantic inflow greatly influences the deepwater circulation at least down to $400-500 \mathrm{~m}$, and this could facilitate a significant transport of deepwater plankton and micronekton into the Skagerrak deepwater. This potentially important supplementary source of energy and matter for the deep-water fish community has not been quantified.

The fish community inhabiting the Skagerrak deep-water resembles that found in deep fjords and shelf troughs off western Norway (Bergstad, 1990a). The dominance of C. rupestris is similar to that observed in warmer North Atlantic slope waters, e.g. to the west of the British Isles (e.g. Gordon and Duncan, 1985) and south of Iceland (Magnusson and Magnusson, 1995), but the diversity is probably low in the Skagerrak compared with many other of these areas and $A$. silus may not be such a prominent species in slope waters. The great significance of pelagic prey, largely facilitated by vertically migrating plankton and micronekton, has been documented for slope regions where maximum demersal fish abundance coincides with the daytime depth of planktonic and micronectonic prey animals (Blaber and Bulman, 1987; Mauchline and Gordon, 1991; Gordon et al., 1995; Merrett and Haedrich, 1997; Haedrich, 1997). The results from the Skagerrak are thus not unusual. Similar patterns have been observed in deep Norwegian fjords (e.g. Giske et al., 1990) although the literature on linkages to deep-water fish inhabiting fjords is limited. What makes the Skagerrak particularly productive also in deep waters may be the combination of enhanced local surface production in frontal zones, high sedimentation rates, and probably a significant advective production of zooplankton and micronekton. 


\section{Acknowledgements}

The projects that provided data for this work were funded by the University of Bergen, the Institute of Marine Research and the Norwegian Research Council.

\section{References}

AKSNES, D. L., J. AURE, S. KAARTVEDT, T. MAGNESEN, and J. RICHARD. 1989. Significance of advection for the carrying capacity of fjord populations. Mar. Ecol. Prog. Ser, 50: 263-274.

ALBERT, O. T. 1993. Distribution, population structure and diet of silvery pout (Gadiculus argenteus thori J. Schmidt), poor-cod (Trisopterus minutus minutus (L.)), four-bearded rockling (Rhinonemus cimbrius (L.)), and Vahl's eelpout (Lycodes vahlii gracilis Reinhardt) in the Norwegian Deep. Sarsia, 78: 141-154.

1994a. Biology and ecology of Norway pout (Trisopterus esmarki Nilsson, 1855) in the Norwegian Deep. ICES J. Mar.Sci., 51: 45-61.

1994b. Ecology of haddock (Melanogrammus aeglefinus L.) in the Norwegian Deep. ICES J. Mar.Sci., 51: 31-44.

ANON. 1993. North Sea Subregion 8. Assessment Report 1993. North Sea Task Force. Nowegian Pollution Control Authority, 1993, 79 p.

AURE, J., and E. DAHL. 1994. Oxygen, nutrients, carbon and water exchange in the Skagerrak Basin. Cont. Shelf Res., 14: 965-977.

BAGØIEN, E., S. KAARTVEDT, and S. ØVERÅS. 2000. Seasonal vertical migration of Calanus spp. in Oslofjorden. Sarsia, 85: 299-312.

BERGSTAD, O. A. 1990a. Ecology of the fishes of the Norwegian Deeps: Distribution and species assemblages. Neth. J. Sea Res., 25(1/2): 237-266.

1990b. Distribution, population structure, growth and reproduction of the roundnose grenadier Coryphaenoides rupestris (Pisces:Macrouridae) in the deep waters of the Skagerrak. Mar. Biol., 107: 25-39.

1991a. Distribution and trophic ecology of some gadoid fish of the Norwegian Deep. 1. Accounts of individual species. Sarsia, 75: 269-313.

1991b. Distribution and trophic ecology of some gadoid fish of the Norwegian Deep. 2. Food-web linkages and comparisons of diets and distributions. Sarsia, 75: 315-325.

BERGSTAD, O. A. 1993. Distribution, population structure, growth and reproduction of the greater silver smelt, $\mathrm{Ar}$ gentina silus (Pisces, Argentinidae), of the Skagerrak and the north-eastern North Sea. ICES J. Mar. Sci., 50: 129143.

BERGSTAD, O. A., and J. D. M. GORDON. 1994. Deepwater ichthyoplankton of the Skagerrak with special reference to Coryphaenoides rupestris Gunnerus, 1765 (Pisces: Macrouridae) and Argentina silus (Ascanius, 1775)(Pisces, Argentinidae). Sarsia, 79: 33-43.
BERGSTAD, O. A., and S. TVEITE. 1993. Distribution, stock structure and biology of Glyptocephalus cynoglossus in the Skagerrak area. Fisken og Havet, 2(1993): 1-21 (in Norwegian).

BERGSTAD, O. A., E. TORSTENSEN, and B. BØHLE. 1996. Micronekton and pelagic fishes in fjords on the Norwegian Skagerrak coast in winter. Fisken og Havet, 5(1996): 1-25.

BERGSTRÖM, B. I. 2000. The Biology of Pandalus. Adv. Mar. Biol., 38: 57-245.

BLABER, S. J. M., and C. M. BULMAN. 1987. Diets of fishes of the upper continental slope of eastern Tasmania: content, calorific values, dietary overlap and trophic relationships. Mar. Biol., 95: 345-356.

BORODULINA, O. D. 1964. Some data on the biology of the Argentine Argentina silus (Ascanius). Vopr. Ichtiol., 4: $68-81$.

BUCHHOLZ, F., and E. BOYSEN-ENNEN. 1988. Meganyctiphanes norvegica (Crustacea: Euphausiacea) in the Kattegat: studies on the horizontal distribution in relation to hydrography and zooplankton. Ophelia, 29: 71-82.

BØHLE, B., and E. MOKSNESS. MS 1991. On the distribution of euphausiids in Skagerrak. ICES C. M. Doc., No. L:4: 1-5.

BÅMSTEDT, U. 1983. Sekundäproduktion. In: Sitiationen i havsområdet mellan Nordsjön og Östersjön. Proceedings from a Symposium held in Gothenburg, Sweden. B. I. Dybern, J. Söderström and L. Thorell (Eds.). Meddelande från Havsfiskelaboratoriet, Lysekil. Nr., 292: 96-110.

BÅMSTEDT, U., and K. KARLSON. 1998. Euphausiid predation on copepods in coastal waters of the Northeast Atlantic. Mar. Ecol. Prog. Ser., 172: 149-168.

CARTES, J. E. 1993. Feeding habits of pasiphaeid shrimps close to the bottom on the western Mediterranean slope. Mar. Biol., 117: 459-468.

CARTES, J. E., F. SARDA, J. B. COMPANY, and J. LLEONART. 1993. Day-night migrations by deep-sea decapod crustaceans in experimental sampling in the western Mediterranean Sea. J. Exp. Mar. Biol. Ecol., 171: 63-73.

DANIELSSEN, D. S., L. EDLER, S. FONSELIUS, L. HERNROTH, M. OSTROWSKI, E. SVENDSEN, and L. TALPSEPP. 1997. Oceanographic variability in the Skagerrak and Northern Kattegat, May-June, 1990. ICES J. Mar. Sci., 54: 753-773.

DYBERN, B. I. 1969. Invasions of Tima bairdii at the Swedish west coast. Meddelande från Havsfiskelaboratoriet, Lysekil., 75: 1-6.

EMERY, A. R., and F. D. McCRACKEN. 1966. Biology of the Atlantic Argentine (Argentina silus Ascanius) on the Scotian Shelf. J. Fish. Res. Board. Can., 23: 1145-1160.

FONSELIUS, S. 1996. The upwelling of nutrients in the central Skagerrak. Deep-sea Res. II, 43: 57-71.

GARTNER, J. V. Jr., R. E. CRABTREE, and K. J. SULAK. 1997. Feeding at depth. In: Deep-sea Fishes (D. J. Randall and A. P. Farrell (eds.). Fish Physiology, 16: 115-193.

GEISTDORFER, P. 1978. Elologie alimentaire des Macrouridae. Rev. Trav. Inst. Pêches marit., 42: $173-261$. 
GISKE, J., D. L. AKSNES, B. M. BALIÑO, S. KAARTVEDT, U. LIE, J. T. NORDEIDE, A. G. V. SALVANES, S. M. WAKILI, and A. AADNESEN. 1990. Vertical distribution and trophic interactions of zooplankton and fish in Masfjorden, Norway. Sarsia., 75: 65-81.

GORDON, J. D. M., and J. A. R. DUNCAN. 1985. The ecology of the deep-sea benthic and benthopelagic fish on the slopes of the Rockall Trough. Prog. Oceanog., 15: 37-69.

GORDON, J. D. M., N. R. MERRETT, and R. L. HAEDRICH. 1995. Environmental and biological aspects of slope-dwelling fishes of the North Atlantic. In: Deepwater fisheries of the North-Atlantic Oceanic Slope (A. G. Hopper (ed.). Kluwer Academic Publishers, The Netherlands, p. 1-26.

GORDON, J. D. M., O. A. BERGSTAD, I. FIGUEIREDO, and G. MENEZES. 2002. Deep-water fisheries of the Northeast Atlantic: I Description and current trends. J. Northw. Atl. Fish. Sci., 31: 137-150 (this volume).

HAEDRICH, R. L. 1974. Pelagic capture of the epibenthic rattail Coryphaenoides rupestris. Deep-sea Res., 21: 971-977.

HAEDRICH, R. L. 1997. Distribution and population ecology. In: Deep-sea Fishes. D. J. RANDALL and A. P. FARRELL (eds.). Fish Physiology, 16: 79-114.

HILDRE, Ø. MS 2001. Diettanalyse for smørflyndre (Glyptocephalus cynoglossus) i Norskerenna. Thesis, University of Oslo, in submission.(in Norwegian).

HOPKINS, C. C. E., P. E. GROTNES, and J. E. ELIASSEN. 1989. Organization of a fjord community at $70 \mathrm{~N}$ : The pelagic food web in Balsfjord, northern Norway. ICES Rapp. Proc.,-Verb., 188: 146-153.

ICES. 2001. Report of the Advisory Committee on Fisheries Management. ICES Coop. Res. Rep., 242: 1-910.

KARHU, M., and A. LEEBEN. 1991. Size structure of planktonic particles in relation to hydrographic structure in the Skagerrak. Mar. Ecol. Prog. Ser., 76: 159-166.

KAARTVEDT, S. 1999. Plankton behaviour and life cycles in advective environments In: Aquatic life cycle strategies. Survival in a variable environment. M. Whitfield, J. Matthews and C. Reynolds (eds.). Marine Biological Association of the United Kingdom, Plymouth, UK, p. 45-52.

KAARTVEDT, S., D. L. AKSNES, and A. AADNESEN. 1988. Winter distribution of macroplankton and micrronekton in Masfjorden, western Norway. Mar. Ecol. Prog. Ser., 45: $45-55$.

KEYSLER, H. D. 1968. Investigations on the stocks of $A r-$ gentina silus in the waters off Norway, Iceland and Newfoundland. ICES Rapp. Proc.,-Verb., 158: 58-64.

KIØRBOE, T., H. KAAS, B. KRUSE, F. MØHLENBERG, P. TISELIUS, and G. ÆRTEBJERG. 1990. The structure of the pelagic food web in relation to water column structure in the Skagerrak. Mar. Ecol. Prog. Ser., 59: 19-32.

LAMPITT, R. S., K. F. WISHNER, C. M. TURLEY, and M. V. ANGEL. 1993. Marine snow studies in the Northeast Atlantic Ocean: distribution, composition and role as food source for migrating plankton. Mar. Biol., 116: 689-702.

LJØEN, R., and A. SVANSSON. 1972. Long-term variations of subsurface temperatures in the Skagerrak. Deep-Sea Res., 19: 277-288.

LONGVA, O., and T. THORSNES. 1997. Skagerrak in the past and at the present- and integrated study of geology, chemistry, hydrography and micro-fossil ecology. Geological Survey of Norway, Special Publication, No. 8, $98 \mathrm{p}$.

MAGNUSSON, J. V., and J. MAGNUSSON. 1995. The distribution, relative abundance and the biology of the deepsea fishes of the Icelandic slope and Reykjanes Ridge. In: Deep-water fisheries of the North-Atlantic Oceanic Slope. A. G. Hopper (ed.). Kluwer Academic Publishers, The Netherlands, $420 \mathrm{p}$.

MATTHEWS, J. B. L., and B. R. HEIMDAL. 1980. Pelagic productivity and food chains in fjord systems. In: Fjord Oceanography. H. J. Freeland, D. M. Farmer, and C. D. Levings (eds.). NATO Conference Series IV, Marine Sciences, Vol. 4: 377-398. Plenum Press, New York and London.

MATTSON, S. 1981. The food of Galeus melastomus, Gadiculus argenteus thori, Trisopterus esmarkii, Rhinonemus cimbrius, and Glyptocephalus cynoglossus (Pisces) caught during the day with shrimp trawl in a west-Norwegian fjord. Sarsia, 66: 109-127.

MAUCHLINE, J. 1980. The biology of mysids and euphausiids. Adv. Mar. Biol., 18: 1-681.

MAUCHLINE, J., and J. D. M. GORDON. 1983. Diets of clupeoid, stomiatoid and salmonid fish of the Rockall Trough, northeastern Atlantic. Mar. Biol., 77: 67-78.

MAUCHLINE, J., and J. D. M. GORDON. 1984. Diets and bathymetric distribution of the macrourid fish of the Rockall Trough, Atlantic Ocean. Mar. Biol., 81: 107121.

MAUCHLINE, J., and J. D. M. GORDON. 1991. Oceanic pelagic prey of benthopelagic fish in the benthic boundary layer of a marginal oceanic region. Mar. Ecol. Prog. Ser., 74: 109-115.

MAUCHLINE, J., O. A. BERGSTAD, J. D. M. GORDON, and T. BRATTEGARD. 1994. The food of juvenile Coryphaenoides rupestris Gunnerus, 1765 (Pisces, Macrouridae) in the Skagerrak. Sarsia, 79:163-164.

MERRETT, N. R., and R. L. HAEDRICH. 1997. Deep-Sea Demersal Fish and Fisheries. Chapman and Hall, London. 282 p.

MISKOV-NODLAND, K., L. BUHL-MORTENSEN, and T. HØISÆTER. 1999. Has the fauna in the deeper parts of the Skagerrak changed?: A comparison of the present amphipod fauna with observations from 1933/37. Sarsia, 84: $137-155$.

NASH, R. D. M. 1985. The distribution of fish in the Oslofjord and its possible relationship to pollution. In: Marine Biology of Polar Regions and Effects of Stress on Marine Organisms. J. S. Gray and M. E. Christiansen (eds.). J. Wiley \& Sons Ltd, p. 389-400.

ONSRUD, M. S. R., and S. KAARTVEDT. 1998. Diel vertical migration of the krill Meganyctiphanes norvegica in relation to physical environment, food and predators. Mar. Ecol. Prog. Ser., 171: 209-219.

OTTO, L., J. T. F. ZIMMERMAN, G. K.FURNES, M. MORK, 
R.SÆTRE, and G. BECKER.1990. Review of the physical oceanography of the North Sea. Neth. J. Sea Res., 26: $161-238$.

PECHENIK, L. N., and F. M. TROYANOVSKY. 1970. Trawling resources on the North Atlantic continental slope. Israel Program for Scientific Translations, 1971, Cat. No. 5977, 66 p.

PODRAZHANSKAYA, S. G. 1968. Feeding of Macrourus rupestris in the Icelandic area. Annls. Biol. Copenh., 24(1967): 197-198.

RICHARD, J. M., and R. L. HAEDRICH. 1991. A comparison of the macrozooplankton faunas in two Newfoundland fjords differing in physical oceanography. Sarsia, 76: 41-52.

ROHDE, J. 1996. On the dynamics of the large-scale circulation of the Skagerrak. J. Sea Res., 35: 1-8.

ROSENBERG, R., B. HELLMAN, and A. LUNDBERG. 1996. Benthic macrofaunal community structure in the Norwegian Trench, deep Skagerrak. J. Sea Res., 35: 181-188.

RYDBERG, L., J. HAAMER, and O. LIUNGMAN. 1996. Fluxes of water and nutrients within and into the Skagerrak. J. Sea Res., 35: 23-38.

SHUMWAY, S.E., PERKINS, H.C., SCHICK, D.F., and A.P. STICKNEY. 1985. Synopsis of biological data on the Pink shrimp, Pandalus borealis Krøyer, 1838. FAO Fisheries Synopsis, 144: 1-57.

SKJÆRAASEN, J. E. 1998. Skater (Pisces: Rajidae) i Norskerenna og langs norsk kontinentalskråning: utbredelse, ernæring og biologi. Thesis, University of Trondheim, Norway. $89 \mathrm{p}$.

SKJÆRAASEN, J. E., and O. A. BERGSTAD. 2000. Distribution and feeding ecology of Raja radiata in the northeastern North Sea and Skagerrak (Norwegian Deep).
ICES J. Mar. Sci., 57: 1249-1260.

SKJÆRAASEN, J. E., and O. A. BERGSTAD. 2001. Notes on the distribution and length composition of Raja lintea, $R$. fyllae, R. hyperborea and Bathyraja spinicauda (Pisces: Rajidae) in the deep northeastern North Sea and on the slope of the eastern Norwegian Sea. ICES J. Mar. Sci., 58: 21-28.

SQUIRES, H. J. 1990. Decapod Crustacea of the Atlantic coast of Canada. Can. Bull. Fish. Aquat. Sci., 221: 1-532.

SVANSSON, A. 1975. Physical and chemical oceanography of the Skagerrak and the Kattegat. I. Open sea conditions. Rep. Fish. Bd. Sweden, Inst. Mar. Res., 1: 1-88.

TAMBS-LYCHE, H. 1987. The natural history of the Hardangerfjord. 14. Fishes. Sarsia, 72: 101-124.

TISELIUS. P., T.G. NIELSEN, G. BREUEL, A. JAANUS, A. KORSCHENKO and Z. WITEK. 1991. Copepod egg production in the Skagerrak during SKAGEX, May-June 1990. Mar. Biol., 111: 445-453.

VINOGRADOV, M. E. 1997. Some problems of vertical distribution of meso- and macroplankton in the ocean. $A d v$. Mar. Biol., 32: 1-92.

WESTHAUS, P. 1982. Fischereibiologische Untersuchungen am Goldlachs (Argentina silus) im Seegebiet der Shetland-Färöer-Inseln und in Gewässern westlich von Grossbritanniens. Arch. Fisch Wiss., 32: 13-28.

WIK, Å. D. MS 1994. Svarthå (Etmopterus spinax, L.,1758) og havmus (Chimaera monstrosa, L., 1758) i Norskerenna: Utbredelse, biologi og ernærings $\varnothing$ kologi. Thesis, University of Oslo, Norway, 79 p.

WOOD, R. J., and D. F. S. RAITT. 1968. Some observations on the biology of the greater silver smelt, particularly in the north-eastern Atlantic Ocean. ICES Rapp. Prob.Verb., 158: 64-73. 